\title{
Glyceride structure and sterol composition of SOS-7 halophyte oil.
}

\author{
By S.M. El-Shami
}

Fats and Oils Dept., National Research Centre.

Dokki, Cairo, Egypt.

\section{RESUMEN}

Estructura glicerídica y composición esterólica de aceite de halofito SOS-7.

Se ha estudiado usando la técnica de hidrólisis mediante lipasa la estructura glicerídica de aceite de halofito SOS-7. Esta muestra de halofito fue obtenida a partir de una cosecha de 1988 plantada en Ghardaka, en la orilla del Mar Rojo, Egipto.

Para la extracción del aceite de la semilla molida se utilizó hexano comercial en extractor Soxhlet.

Los ácidos grasos insaturados se encontraron centralizados en la posición 2 de los triglicéridos, siendo los ácidos oleíco y linolénico los que mostraron mayor preferencia por esta posición. Se encontró que $P_{3}$ fue el componente mayoritario de $G_{3}$, mientras que $P_{2} L$ y PStL; $\mathrm{PL}_{2}$ POL y $\mathrm{StL}_{2}$ son los predominantes para $\mathrm{GS}_{2} \mathrm{U}$ y $\mathrm{GSU}_{2}$ respectivamente. $L_{3}$ se manifestó como el principal constituyente de los $\mathrm{GU}_{3}$.

La composición esterólica del aceite de halofito se determinó por GLC como derivados del TMS.

Se encontró que el aceite contenía campesterol, B-sitosterol, estigmasterol y 7-estigmasterol siendo este último el esterol mayoritario con un porcentaje del 52,4.

PALABRAS-CLAVE: Aceite de halofito SOS-7 - Esterol (composición en) - Glicérido (estructura).

\section{SUMMARY}

Glyceride structure and sterol composition of SOS-7 halophyte oil.

Glyceride structure of SOS-7 halophyte oil was studied using the lipase hydrolysis technique. This halophyte sample was obtained from 1988 harvest planted in Ghardaka, on the border of the Red Sea, Egypt. The oilseed was ground and extracted for its oil using commercial hexane in Soxhlet extractor. The unsaturated fatty acids were found centralized in the 2-position of triglycerides, whereas oleic and linolenic acids showed more preference for this position. It was found that $P_{3}$ was the major component of $G S_{3}$, whereas $P_{2} L$ and PStL; $P L_{2}, P O L$ and $\mathrm{StL}_{2}$ are predominating among $\mathrm{GS}_{2} \mathrm{U}$ and $\mathrm{GSU}_{2}$ respectively. $\mathrm{L}_{3}$ manifested itself as the principal constituent of $\mathrm{GU}_{3}^{2}$ type.

Sterol composition of the halophyte oil was determined by GLC as TMS derivative. It was found that the oil contains campsterol, Bsitosterol, stigmasterol and 7-stigmasterol of which 7-stigmasterol is the major sterol and constitute $52.4 \%$.

KEY-WORDS: Glyceride (structure) - SOS-7 halophyte oil - Sterol (composition in).

\section{INTRODUCTION}

Egypt suffers from the shortage of edible oils and large tonnages of oils have been imported (about 500,000 tons) from the foreign market to meet the - increasing local consumption amounting to 620,000 tons per year. Since local cottonseed oil production does not cover the requirements of local consumption of oils, several trials have been made to increase the cultivated area with oil seed crops, namely, soybean and sunflower with an attempt to fulfill the needs of local requirements. However, desert cultivation with new oilseed crops, as salt and climatic tollerant, have been successfully tried in small desert area in Egypt.

The Environmental Research Lab., ERL, Arizona (1), initiated the work in the field of halophyte plants and in particular, halophyte SOS-7. In continuation to the previous study in this Lab. (2) on characterizing halophyte, SOS-7, oil produced from locally cultivated halophyte plant, it was of interest to carry out further studies dealing with quantitative determination of the glyceride pattern of such oil. In addition, sterol components of the oil was also investigated using high efficient separation column of GLC as well as masscoupling for confirming the structure of the sterol components.

\section{GLYCERIDE STRUCTURE}

\subsection{Experimental}

A sample from 1988 harvest of SOS-7 halophyte planted in Ghardaka, on the border of the Red Sea, Egypt, was used in this study. The oil seeds were ground and extracted for their oil using commercial hexane (b.r. $63-68^{\circ} \mathrm{C}$ ) in Soxhlet extractor. The solvent was evaporated under reduced pressure and the resulting oil (25.3\% of the weight of the seeds) was kept in well stoppered bottles in refrigerator until use. 


\section{Oil Analysis and Lipolysis}

The oil characteristics were determined in a previous work (2). Part of the oil was converted into methyl esters using $\mathrm{HCl}$ gas as a catalyst (3) and the fatty acid composition of the oil was determined by gas liquid chromatographic analysis. Perkin Elmer Fractometer - FID7 with flame ionization detector and a column DEGS on chromosorb $\mathrm{A}$ was used at $190^{\circ} \mathrm{C}$. The nitrogen, hydrogen and oxygen flow rates were 70,25 and $300 \mathrm{ml} / \mathrm{min}$, respectively.

Lipolysis of one gram sample was carried out in duplicate using $100 \mathrm{mg}$ pork lipase according to Coleman and Fulton (4). After 30 minutes from the begining of hydrolysis, about $60-70 \%$ of the original oil was converted into 2-monoglycerides, and the reaction was stopped by acidification. The hydrolyzed lipids were extracted with diethyl ether and washed till neutral, dried over anhydrous sodium sulphate and filtered. The solvent was removed under reduced pressure to obtain the residual lipids. The latter were dissolved in chloroform and separated by TLC using $0.5 \mathrm{~mm}$ layer silica gel $G$ preparative plates and petroleum ether -diethyl ether- acetic acid (60:40 : 1 V/V/V) as the developing solvent. The located monoglyceride band was scraped off the TLC plate and eluted with chloroform. The solvent was removed and the monoglycerides were converted to their methyl esters (3) and the fatty acid composition of the 2monoglycerides (2-MGS) was determined by GLC. The procedure and conditions of the analysis were the same as those used for the analysis of the fatty acid composition of the original oil.

From the fatty acid composition of the 2-MGS and the calculated fatty acids in 1- and 3-position, the distribution of fatty acyls in the original triglycerides was calculated according to Coleman (5). The relative proportion (r.p.) representing the percentages of fatty acid in question in the 2-MG, was also calculated (6) (7).

\subsection{Results and discussion}

The fatty acid composition of the halophyte oil seed is recorded in table I. This oil contains high content of unsaturated fatty acids (84.7\%) which is characteristic of the vegetable oils, among them linoleic acid is the major constituent and forms $69 \%$ of the total fatty acids. The other two unsaturated fatty acids, namely oleic and linolenic constitute 14.3 and $1.4 \%$ of the mixed fatty acids. Saturated fatty acids represented by palmitic and stearic acids are detected in the halophyte oil forming 10.5 and $4.8 \%$, respectively.

The component fatty acids of the 2-MGS resulting from lipolysis in comparison with those present in the whole triglyceride are shown in table I. r.p. values as a measure of the preference of each fatty acid in question for 2- and 1,3- positions are recorded also in table I. From the results, it can be seen that palmitic acid is preferentially esterified at 1- and 3-positions in the whole triglycerides since the r.p. value is lower than the random value of $33.3 \%(8)$. This is in agreement with the general distribution pattern of the saturated fatty acids reported for vegetable oils (6) (7) (8) (9) (10). Oleic and linolenic acids show high r.p. values corresponding to 51.3 and 50 , respectively, indicating that oleic and linolenic acids compete nearly equally for the 2-position. Whereas linoleic having r.p. value of 35.7 shows comparatively low preference for the 2-position than oleic and linolenic acids. Gene-

Table 1

Fatty Acid Composition of the Halophyte Oil Seed and the Corresponding 2-monoglycerides (2-MG) (Mole \%)

\begin{tabular}{lcrc}
\hline Fatty Acid & $\begin{array}{c}\text { Whole TG } \\
\text { (Fatty Acid } \\
\text { compn.) }\end{array}$ & 2-MG & r.p.* \\
\hline Palmitic & 10.5 & 1.8 & 5.7 \\
Stearic & 4.8 & zero & zero \\
Oleic & 14.3 & 22.0 & 51.3 \\
Linoleic & 69.0 & 74.1 & 35.7 \\
Linolenic & 1.4 & 2.1 & 50.0 \\
\end{tabular}

\footnotetext{
*r.p. (Relative proportion) = F.A.\% in 2-MG $\times 100 /$ F.A.\% in whole

TG $\times 3$; r.p. values exceeding $33.3 \%$ show more preference to $2-$ po

sition.
} 
Table II

Component glycerides (Mole \%)

\begin{tabular}{|c|c|c|c|c|c|c|c|}
\hline \multicolumn{2}{|c|}{$\mathrm{GS}_{3}$} & \multicolumn{2}{|c|}{$\mathrm{GS}_{2} \mathrm{U}$} & \multicolumn{2}{|c|}{$\mathrm{GSU}_{3}$} & \multicolumn{2}{|c|}{$\mathrm{GU}_{3}$} \\
\hline Glyceride & $\begin{array}{c}\text { Mole } \\
\%\end{array}$ & Glyceride & $\begin{array}{c}\text { Mole } \\
\%\end{array}$ & Glyceride & $\begin{array}{c}\text { Mole } \\
\%\end{array}$ & Glyceride & $\begin{array}{c}\text { Mole } \\
\%\end{array}$ \\
\hline $\mathrm{P}_{3}$ & 0.05 & $\mathrm{P}_{2} \mathrm{O}$ & 0.62 & $\mathrm{PO}_{2}$ & 0.72 & $\mathrm{O}_{3}$ & 0.23 \\
\hline$S t_{2} P$ & 0.04 & $\mathrm{St}_{2} \mathrm{O}$ & 0.11 & $\mathrm{PL}_{2}$ & 16.37 & $\mathrm{~L}_{2} \mathrm{O}$ & 19.39 \\
\hline $\mathrm{P}_{2} \mathrm{St}$ & 0.01 & PSto & 0.52 & $\mathrm{PLn}_{2}$ & 0.01 & $\mathrm{LO}_{2}$ & 3.71 \\
\hline- & - & $\mathrm{P}_{2} \mathrm{~L}$ & 2.30 & POL & 7.25 & $\mathrm{LnO}_{2}$ & 0.07 \\
\hline- & - & $S t_{2} L$ & 0.40 & POLn & 0.14 & LnOL & 0.75 \\
\hline- & - & PStL & 1.88 & PLLn & 0.72 & LnOLn & 0.01 \\
\hline - & - & $\mathrm{P}_{2} \mathrm{Ln}$ & 0.06 & $\mathrm{StO}_{2}$ & 0.32 & $\mathrm{LnL}_{2}$ & 1.93 \\
\hline - & - & $S t_{2} \operatorname{Ln}$ & 0.01 & $\mathrm{StL}_{2}$ & 6.86 & $\operatorname{LLn}_{2}$ & 0.04 \\
\hline - & - & PStLn & 0.05 & $\operatorname{StLn}_{2}$ & 0.00 & $\mathrm{Ln}_{3}$ & 0.00 \\
\hline - & - & - & - & StOL & 3.10 & $\mathrm{~L}_{3}$ & 31.98 \\
\hline - & - & - & - & Stoln & 0.06 & - & - \\
\hline- & - & - & - & StLLn & 0.31 & - & - \\
\hline Total & 0.10 & Total & 5.95 & Total & 35.86 & Total & 58.11 \\
\hline
\end{tabular}

rally, the proportionally high concentration of oleic, linolenic and linoleic acids in the 2-position has been ascribed to the fact that specific distribution of saturated acids (in this case palmitic and stearic acids) in 1- and 3-position forces a higher proportion of oleic, linoleic and linolenic in the 2-position of the triglyceride molecules (6) (11). Concerning the type of glycerides calculated, namely, trisaturated $\left(G S_{3}\right)$, disaturated $\left(G S_{2} U\right)$, monosaturated $\left(G S U_{2}\right)$ and triunsaturated $\left(\mathrm{GU}_{3}\right)$, the results are recorded in table II.

The component triglycerides of $\mathrm{GS}_{3}$ type, contain tripalmitin $\mathrm{P}_{3}$ and distearo-palmitin $\left(\mathrm{St}_{2} \mathrm{P}\right)$ as major components constituting 0.05 and $0.04 \%$ respectively, whereas dipalmito-stearin $\left(\mathrm{P}_{2} \mathrm{St}\right)$ is found in lower concentration of $0.01 \%$.

Concerning the $G S_{2} U$, it can be noticed that dipalmito-linolein $\left(\mathrm{P}_{2} \mathrm{~L}\right)$ and palmito-stearo-linolein (PStL) are present as major components in halophyte oil. Dipalmito-olein $\left(\mathrm{P}_{2} \mathrm{O}\right)$, palmito-stearo-olein (PStO) and distearo-linolein $\left(\mathrm{S}_{2} \mathrm{~L}\right)$ are found in comparatively low concentrations (0.62, 0.52 and $0.4 \%$ respectively). Minor triglyceride components of the $\mathrm{GS}_{2} \mathrm{U}$ type, namely, $\mathrm{St}_{2} \mathrm{O}, \mathrm{P}_{2} \mathrm{Ln}, \mathrm{St}_{2} \mathrm{Ln}$ and $\mathrm{PSt}$ are also detected. It can be generally concluded that halophyte oil attains high $\mathrm{P}_{2} \mathrm{~L}$ and $\mathrm{PStL}$.
With reference to component glycerides of the $\mathrm{GSU}_{2}$ type (table II), palmito-dilinolein $\left(\mathrm{PL}_{2}\right)$ is the major component which constitutes $16.37 \%$ of the total $\mathrm{GSU}_{2}$ type. Palmito-oleo-linolein (POL), stearo-dilinolein $\left(\mathrm{StL}_{2}\right)^{2}$ and stearo-oleo-linolein (StOL) are present in moderate concentrations amounting $7.25,6.86$ and $3.10 \%$ respectively, whereas $\mathrm{PO}_{2}, \mathrm{PLLn}, \mathrm{StO}_{2}$ and StLLn are found in low concentrations $(0.72,0.72,0.32$ and $0.31 \%$ respectively). Other minor triglycerides of the type $\mathrm{GSU}_{2}$, namely, $\mathrm{PLn}_{2}, \mathrm{POLn}, \mathrm{StLn}_{2}$ and StOLn are also detected.

From the results representing glyceride components of the $\mathrm{GU}_{3}$ type, it can be seen that trilinolein $\left(\mathrm{L}_{3}\right)$ constitutes 31.98 which corresponding to more than $50 \%$ of the $\mathrm{GU}_{3}$ type. Oleodilinolein $\left(\mathrm{L}_{2} \mathrm{O}\right)$ comes after $\mathrm{L}_{3}$ (19.39 mole\%) which corresponding to nearly $33 \%$ of the total $\mathrm{GU}_{3}$ type. $\mathrm{LO}_{2}$ and $\mathrm{LnL}_{2}$ are present in comparatively low concentrations $(3.71$ and 1.93 respectively). $\mathrm{O}_{3}, \mathrm{LnO}_{2}, \mathrm{LnOL}, \mathrm{LnOLn}, \mathrm{LLn}_{2}$ and $\mathrm{Ln}_{3}$ are detected in minor amounts.

From the above results, it can be concluded that the 2-position in the halophyte triglycerides is mainly occupied by the unsaturated $\mathrm{C}_{18}$ which agrees with other investigators (4) (6) (7) (9) and this also confirms the non-random character of the acyl group 
distribution in vegetable oil glycerides and has led to the wide acceptance of the theory of positional distribution (5) (12) (13) (14) in place of other theories.

\section{STEROL COMPOSITION}

\subsection{Experimental}

Identification and quantitative determination of sterols were carried out using reference standards in ethanol (campsterol, stigmasterol, B-sitosterol and 7stigmasterol) as well as cholesterol as internal standard (IS). The procedure of Slover et al (15) was applied for the identification and determination of the sterol components.

\section{Preparation of Pure Sterols}

A mixture of oil sample $(0.5 \mathrm{~g})$ and $5 \mathrm{ml}$ of $\mathrm{IS}$ was saponified with alcoholic $1 \mathrm{~N} \mathrm{KOH}$ for one hour on a water bath. The sterol fraction was separated from the unsaponifiable matter by preparative TLC on silica gel G plates (0.5 mm thick) using chloroform / ether / acetic acid ( $94 / 5 / 1, \mathrm{~V} / \mathrm{V} / \mathrm{V})$. Sterols mixture was subjected to silylating reaction using two parts of hexamethyl-disilazane and one part of trimethyl-chlorsilane with ten parts of dry pyridine. After standing for at least 15 minutes at rocm temperature, the mixture was injected directly into gas chromatograph (15).

\section{Gas Liquid Chromatography GLC*}

Hewlett Packard - HP 5890 A, gas chromatograph equipped with flame ionization detector and $2 \mathrm{~m}$ $x 4 \mathrm{~mm}$ glass column packed with $3 \%$ OV-1 on Gas Chrome Q (80-100 mesh) was used. The operating temperatures were: Column $270-280^{\circ} \mathrm{C}$, injection and detector $280^{\circ} \mathrm{C}$. Nitrogen gas was used as carrier gas at $40 \mathrm{ml} / \mathrm{min}$.

\section{Gas Liquid Chromatography - Mass Spectro-} metry GC - MS*

An instrument Hitachi M-80 B was used for this purpose under the following conditions: Column Diasolid ZS $2 \mathrm{~m} \times 4 \mathrm{~mm}$; carrier gas, helium at $35 \mathrm{ml} / \mathrm{min}$; oven temperature, $270^{\circ} \mathrm{C}$; interface temperature, $280^{\circ} \mathrm{C}$; ionization voltage, $20 \mathrm{ev}$; ionization mode, electric (EI) and ion source temperature $200^{\circ} \mathrm{C}$. The effluent arriving the mass spectrometer was detected by total ionization monitor.

Table III

Principal Fragmentations of Sterol Components of Halophyte Seed Oil in GC-MS.

\begin{tabular}{lccc}
\hline Camps terol & Stigmasteral & $\beta$-Sitosterol & 7-Stigmasterol \\
$\Delta^{5}, C_{28}$ & $\Delta^{5,22}, C_{29}$ & $\Delta^{5}, C_{29}$ & $\Delta^{7,22}, C_{29}$
\end{tabular}

\begin{tabular}{|c|c|c|c|c|}
\hline & $\mathrm{M} / \mathrm{e}$ & $\mathrm{M} / \mathrm{e}$ & $\mathrm{M} / \mathrm{e}$ & $\mathrm{M} / \mathrm{e}$ \\
\hline 473 & $\mathrm{M}^{+}$ & $485 \mathrm{M}^{+}$ & $487 \mathrm{M}^{+}$ & $487 \mathrm{M}^{+}$ \\
\hline 458 & $\mathrm{M}-\mathrm{CH}_{3}$ & $470 \mathrm{M}-\mathrm{CH}_{3}$ & $472 \mathrm{M}-\mathrm{CH}_{3}$ & $472 \mathrm{M}-\mathrm{CH}_{3}$ \\
\hline 382 & M-OT'MS & $394 \mathrm{M}-(\mathrm{OTMS}+2 \mathrm{H})$ & $396 \mathrm{M}-\left(\mathrm{O}^{\prime} \mathrm{TMS}+2 \mathrm{H}\right)$ & $396 \mathrm{M}-(\mathrm{OTMS}+2 \mathrm{H})$ \\
\hline 367 & $\mathrm{M}-\left(\mathrm{OTMS}+\mathrm{CH}_{3}+2 \mathrm{H}\right)$ & $379 \mathrm{M}-\left(\mathrm{OTMS}+\mathrm{CH}_{3}+2 \mathrm{H}\right)$ & $381 \mathrm{M}-\left(\mathrm{OTMS}+\mathrm{CH}_{3}+2 \mathrm{H}\right)$ & $381 \mathrm{M}-\left(\mathrm{OTMS}+\mathrm{CH}_{3}+2 \mathrm{H}\right)$ \\
\hline 343 & $\mathrm{M}-\left(\right.$ side chain $\left.+\mathrm{H}_{2} \mathrm{O}\right)$ & $344 \mathrm{M}-($ side chain $+2 \mathrm{H})$ & & $345 \mathrm{M}-($ side chain +1$)$ \\
\hline 255 & $M-($ side chain & $255 \mathrm{M}$-(side chain & $255 \mathrm{M}-$ (side chain & $255 \mathrm{M}$-(side chain \\
\hline & $\left.+\mathrm{CH}_{3}+2 \mathrm{H}\right)$ & $+0 T M S+2 \mathrm{H})$ & $+\mathrm{OTMS}+2 \mathrm{H})$ & $+O T M S+2 H)$ \\
\hline
\end{tabular}

\subsection{Results and discussion}

The GLC analysis of mixed sterols of halophyte oil reveal the presence of four sterols which stand for campsterol, stigmasterol, B-sitosterol and 7-stigmasterol at ratios of $1.3,7.3,39.0$ and $52.4 \%$ respectively. Since the oil appears to be unique in its sterol composition, it was advisable that the sterol components should be subjected to GC - MS for elucidating

\footnotetext{
* In Japan
}

their structures. The effluent passing to mass spectrometer from the gas chromatograph is detected by Total Ion Monitor (TIM) and the mass spectra of the components are obtained. Mass spectra of 7-stigmasterol, as a representative sterol, is shown in the figure. It was found that the sterols detected by GLC are confirmed by GC - MS to be campsterol, stigmasterol, B-sitosterol and 7-stigmasterol as shown from the $\mathrm{m} /$ e fragments (table III). The fragments from 7-stigmasterol of halophyte, major sterol, found to be similar to those reported by Itoh et al (16). The presence of 7- 

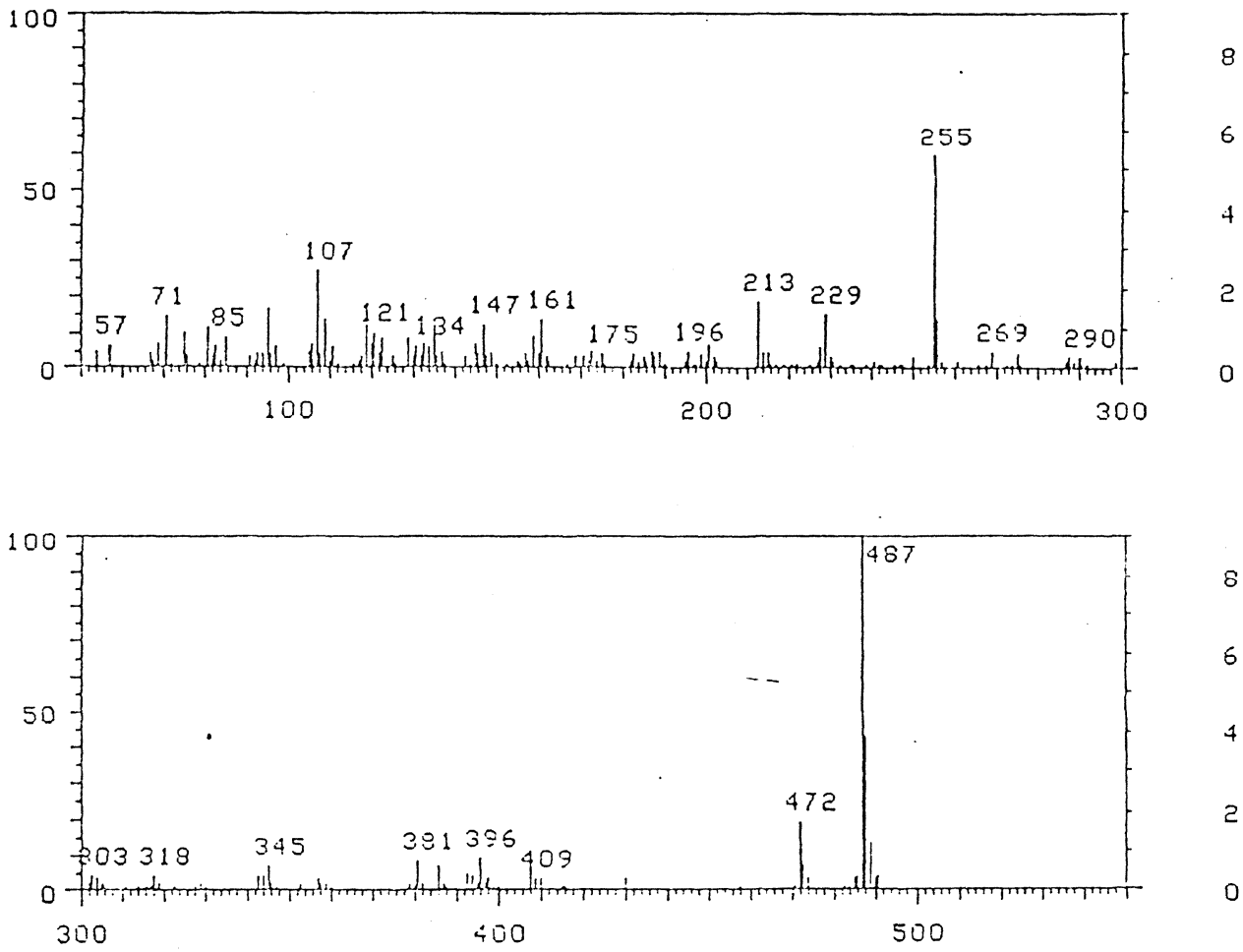

Mass Spectrum of TMS Sterol Taken at the Peak .Corresponding to 7-Stigmasterol on GLC Column.

stigmasterol as major constituent of halophyte sterols is peculiar and is unlike other plants which has Bsitosterol as a major component.

\section{ACKNOWLEDGMENT}

The author wishes to express her sincere thanks to Prof. Dr. M. El-Mallah (NRC, Egypt) and Mr. T. Murui of Res. Lab. (Nisshin Mill, Japan) for offering some help in interpretation and analysis of sterols.

\section{REFERENCES}

1. "SOS-7 An Oil/Forage Halophyte Crop for Egypt".-Proposal Submitted by Halophyte Enterprises Partnership, 1988.

2. El-Nomaany, H.M.; El-Shami, S.M., and Zaher, F.A.-"Characteristics of SOS-7. Halophyte Oil and its Oxidative Stability Compared to Cottonseed Oil".-Grasas y Aceites $\mathbf{4 1}$ (1990) 154-157.

3. Christie, W.W.-“Lipid Analysis”.-Pergamon Press (1973) 87.

4. Coleman, M.H. and Fulton, W.C.-in "The Enzymes of Lipid Metabolism".-P. Desnuelle (Ed.), Pergamon Press, N.Y. (1961) 127.

5. Coleman, M.H.-"The Pancreatic Hydrolysis of Natural Fats. III. The Influence of the Extent of Hydrolysis on Monoglyceride Composition."-J. Am. Oil Chemists' Soc. 40 (1963) 568571.-lbid.-"Further Studies on the Pancreatic Hydrolysis of Some Natural Fats".-38 (1961) 685-688.

6. Mattson, F.H. and Volpenhein, R.A.-"Specific Distribution of Fatty Acids in the Glycerides of Vegetable Fats".-J. Biol. Chem. 236 (1961) 1891-1894.
7. Mattson, F.H. and Lutton, E.S.-"The Specific Distribution of Fatty Acids in the Glycerides of Animal and Vegetable Fats".-J. Biol. Chem. 233 (1958) 868-871.

8. Sharma C.B. and Martinez, G.C.-"The Component Triglycerols of Avocado Fruit-Coat".-J. Am. Oil Chemists' Soc. 49 (1972) 229-232.

9. Mattson, F.H. and Volpenhein, R.A.-"The Specific Distribution of Unsaturated Fatty Acids in the Triglycerides of Plants".-J. Lipid Res. 4 (1963) 392-396.

10. Savary, P; Flanzy, J. and Desnuelle, P.-“'Use of Pancreatic Lipase for the Study of the Structure of Naturally Occurring Fats".-Biochim. Biophys. Acta 24 (1957) 414-423.

11. Evans, C.D.; McConnell, D.G.; List, G.R. and Scholfield, C.R.-"Structure of Unsaturated Vegetable Oil Glycerides: Direct Calculation from Fatty Acid Composition". J. Am. Oil Chemists' Soc. 46 (1969) 421-424.

12. Vander Wal, R.J.-"Calculation of the Distribution of the Saturated and Unsaturated Acyl Groups in Fats from Pancreatic Lipase Hydrolysis Data".-J. Am. Oil Chemists' Soc. 37 (1960) 18-20.

13. Gunstone, F.D.-"Distribution of Fatty Acids in Natural Glycerides of Vegetable Origine".-Chem. Ind. 57 (1962) 1214-1223.

14. Gunstone, F.D.; Hamilton, R.J.; Padley, F.B. and llyas, M.Q.-"Glyceride Studies. V. The Distribution of Unsaturated Acyl Groups in Vegetable Triglycerides".-J. Am. Oil Chemists' Soc. 42 (1965) 965-970.

15. Slover, H.T.; Thompson, R.H., Jr. and Merola G.V.--Determination of Tocopherols and Sterols by Capillary Gas Chromatography".-J. Am. Oil Chemists' Soc. 60 (1983) 15241528.

16. Itoh, T.; Tamoura, T. and Matsumoto. T.-"Sterols of 19 Vegetable Oils".-J. Am. Oil Chemists' Soc. 50 (1973) 122-125.

(Recibido: Septiembre 1990) 